\title{
Effects of Quartz Glass Insulation on Platinum Gold Thermocouples
}

\author{
Peter Pavlasek ${ }^{1,2}$, Jan Rybař $\check{\check{2}}^{2}$, Stanislav Ďuriš ${ }^{2}$, Jakub Palenčar ${ }^{2}$ \\ ${ }^{1}$ Slovak Institute of Metrology, Temperature Group, Karloveská, 63., 84255, Bratislava, Slovakia, Pavlasek@smu.gov.sk \\ ${ }^{2}$ Institute of automation, measurement and applied informatics, Faculty of Mechanical engineering, Slovak University of \\ Technology, Nam. Slobody, 17, 81231, Bratislava, Slovakia.
}

\begin{abstract}
$\mathrm{Au} / \mathrm{Pt}$ thermocouples are considered as an alternative to High Temperature Platinum Resistance Thermometers and are one of the prime candidates to replace them as the interpolating instrument of the International Temperature Scale of 1990 (ITS-90) in the temperature range between about $660^{\circ} \mathrm{C}$ and $962{ }^{\circ} \mathrm{C}$. This work presents the results of investigation of two $\mathrm{Au} / \mathrm{Pt}$ thermocouples that used exclusively quartz glass $\left(\mathrm{SiO}_{2}\right)$ as insulation material. Measurements in fixed points of $\mathrm{Zn}, \mathrm{Al}$, and $\mathrm{Ag}$ were realized on these thermocouples as well with interchanged inner insulation made of high purity aluminium oxide $\left(\mathrm{Al}_{2} \mathrm{O}_{3}\right)$. The conducted experiments tested the performance of $\mathrm{Au} / \mathrm{Pt}$ thermocouples with the use of different insulation materials. The measured electromotive forces were found to be sensitive to the replacement of the quartz glass by aluminium oxide as an insulation material of the $\mathrm{Au} / \mathrm{Pt}$ thermocouples. This change of insulation has resulted in a temperature increase up to about $0.5 \mathrm{~K}$ measured at the freezing point of silver. The decreasing insulation resistance of quartz glass at higher temperatures is believed to be the source of thermoelectric instability.
\end{abstract}

Keywords: Au/Pt thermocouple, quartz glass insulation, insulation resistance.

\section{INTRODUCTION}

According to the International Temperature Scale of 1990 (ITS-90), High Temperature Standard Platinum Resistance Thermometers (HTSPRT) are used as interpolation instruments in the temperature range between the freezing points of aluminium $\left(660.323{ }^{\circ} \mathrm{C}\right)$ and silver $\left(961.78{ }^{\circ} \mathrm{C}\right)$ [1]. Their sensitivity to contamination, lack of stability, nonuniqueness effects and poor repeatability are well-known problems [2]-[6]. Au/Pt thermocouples are considered to be an alternative to the HTSPRTs in this temperature range. As further improvements in manufacturing processes of $\mathrm{Au} / \mathrm{Pt}$ thermocouples have been made, an increase of their thermoelectric stability and homogeneity has been achieved. This has resulted in excellent measuring properties which allow reproducible measurements of high accuracies which are better by about one order of magnitude compared with $\mathrm{Pt} / \mathrm{Rh}$ alloyed thermocouples [7]. The task group for the mise en pratique for the definition of the Kelvin of the Consultative Committee for Thermometry (MeP-K, CCT) has recommended further research on $\mathrm{Au} / \mathrm{Pt}$ thermocouples as a potential candidate for a new interpolation instrument within the ITS-90 for the temperature range between the aluminium and silver fixed points [8].

In order to see the typical sensitivity and temperature range of $\mathrm{Au} / \mathrm{Pt}$ thermocouple an emf-temperature dependency is provided in Table 1.
Table 1. Typical emf output of an Au/Pt thermocouple [9].

\begin{tabular}{|c|c|}
\hline emf $[\boldsymbol{\mu} \mathbf{V}]$ & $\mathbf{t}_{\mathbf{9 0}}\left[{ }^{\circ} \mathbf{C}\right]$ \\
\hline 0 & 0 \\
\hline 777.56 & 100 \\
\hline 1844.64 & 200 \\
\hline 3141.26 & 300 \\
\hline 4632.85 & 400 \\
\hline 6300.29 & 500 \\
\hline 8134.22 & 600 \\
\hline 10131.09 & 700 \\
\hline 12289.49 & 800 \\
\hline 13428.71 & 900 \\
\hline 16124.11 & 962 \\
\hline
\end{tabular}

The two $\mathrm{Au} / \mathrm{Pt}$ thermocouples that were subject to the investigation used quartz glass as the outer and inner insulation. The quartz glass tubes have a higher purity of $99.995 \%$ compared to typical purities of $99.7 \%$ of aluminium oxide and have a smoother surface of the inner holes of the insulation tubes compared to aluminium oxide tubes, allowing an easier movement of the thermoelements. In this way the creation of stress relieving coil in hot junction, which is normally used to compensate the effect of the different expansion coefficients of gold and platinum, is no longer required. Instead, the unhindered movement of the 
thermoelements inside the smooth quartz glass tubes avoids the formation of mechanical stress in the thermoelements.

The $\mathrm{Au} / \mathrm{Pt}$ thermocouples marked $\mathrm{Au} / \mathrm{Pt} 12-01$ and $\mathrm{Au} / \mathrm{Pt}$ 13-03 were made of pure platinum wire (99.997\%) supplied by Alfa Aesar. The diameter of the wire was $0.5 \mathrm{~mm}$ and its length was $2 \mathrm{~m}$. The gold wire for Au/Pt 12-01 had a nominal purity of $99.999 \%$ and was supplied by M\&K GmbH. The gold wire for $\mathrm{Au} / \mathrm{Pt}$ 13-03 had an unknown purity and was supplied by Berliner Metallhütten und Halbwerkzeuge (BMHW). Both gold thermoelements had a diameter of $0.5 \mathrm{~mm}$ with a length of $2 \mathrm{~m}$. Before the annealing process, the thermoelements were cleaned by using ethyl alcohol and distilled water. The platinum wires were electrically annealed at about $1300{ }^{\circ} \mathrm{C}$ for seven hours. The gold wires were inserted section by section into an auxiliary insulation tube made of aluminium oxide $\left(99.7 \%, \mathrm{Al}_{2} \mathrm{O}_{3}\right)$ and annealed in a horizontal furnace at $1000{ }^{\circ} \mathrm{C}$ for seven hours. After inserting the thermoelements into the four-tube insulation assembly made of quartz glass, the measuring junction was created by welding the gold and platinum thermoelements together. A cross section of the thermocouple quartz glass insulation tubes can be seen in Fig.1. Each of the tubes used in the inner insulation assembly was $650 \mathrm{~mm}$ long with an inner diameter of $1.5 \mathrm{~mm}$ and had a wall thickness of $0.25 \mathrm{~mm}$. The dimensions of the outer one-end-closed protection tubes were $7 \mathrm{~mm}$ (outer diameter) x $5 \mathrm{~mm}$ (inner diameter) and $650 \mathrm{~mm}$ in length. After assembling, the two $\mathrm{Au} / \mathrm{Pt}$ thermocouples were annealed at $1000{ }^{\circ} \mathrm{C}$ in a horizontal furnace for six hours to remove any physical strains (e.g., cold-work) introduced during mounting.

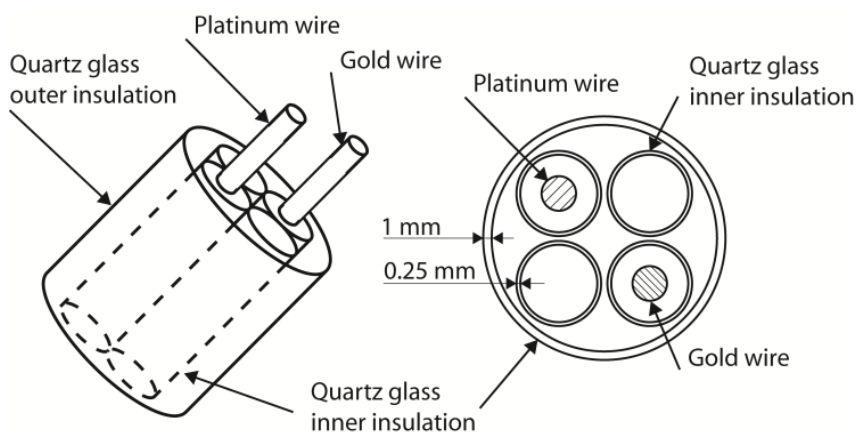

Fig.1. Cross section of the Au/Pt thermocouple with four-tube inner insulation tube and outer insulation made of quartz glass.

\section{MEASUREMENTS}

The measurements presented were arranged in a way to investigate the effects of using different inner insulation materials $\left(\mathrm{SiO}_{2}\right.$ and $\left.\mathrm{Al}_{2} \mathrm{O}_{3}\right)$ on the electromotive force (emf) of both $\mathrm{Au} / \mathrm{Pt}$ thermocouples. These measurements were performed using a calibrated voltmeter and the determined uncertainty $(\mathrm{k}=1)$ of the emf determination was $0.017 \mu \mathrm{V}$ for measurements at $419.527^{\circ} \mathrm{C}, 0.026 \mu \mathrm{V}$ for measurements at $660.32^{\circ} \mathrm{C}$, and $0.044 \mu \mathrm{V}$ for measurements carried out at $961.78^{\circ} \mathrm{C}$. The thermocouple homogeneity, as one of the most important uncertainty contributions affecting their accuracy, was measured, before starting measurements in a fixed point. The homogeneity measurements were performed in a salt bath at a stable temperature of $300^{\circ} \mathrm{C}$ and over a length of $16 \mathrm{~cm}$ of the thermocouples. The thermocouples were fully immersed into a protective tube, which was directly in contact with the liquid salt solution, and slowly raised by $1 \mathrm{~cm}$ steps. The values were recorded after a stabilisation time of $3 \mathrm{~min}$ at each measuring point. Additional homogeneity scanning procedure was performed at the freezing point of silver. The homogeneity was measured by withdrawing the fully emerged thermocouple from the fixed-point cell. The thermoelectric homogeneity was measured over a length of $12 \mathrm{~cm}$ with steps of $2 \mathrm{~cm}$.

The investigation was focused on the effects caused by the use of different insulation inner materials that separate the $\mathrm{Au}$ and $\mathrm{Pt}$ thermocouple wires. This investigation was performed by repeated measurements at the fixed points of $\mathrm{Zn}$ (419.527 $\left.{ }^{\circ} \mathrm{C}\right), \mathrm{Al}\left(660.323^{\circ} \mathrm{C}\right)$, and $\mathrm{Ag}\left(961.78^{\circ} \mathrm{C}\right)$ using $\mathrm{Au} / \mathrm{Pt}$ thermocouples constructed with quartz glass inner insulation tubes and repeated measurements after the insulation replacement for aluminium oxide inner insulation tubes. The results of both of these measurement cycles were compared in order to determine the presence of a leakage effect possibly caused by the inner insulation.

\section{FIXED-POINT MEASUREMENTS}

The fixed-point measurements were performed in three open fixed-point cells of zinc, aluminium, and silver. These measurements were carried out in different vertical threezone furnaces or furnaces equipped with a sodium heat pipe (each fixed point was placed in its own furnace which was optimized for each individual cell). The procedures used were identical to those of a normal fixed-point calibration providing a high level of precision and reproducibility with low uncertainty. The initial measurements were performed in all the fixed-point cells using the $\mathrm{Au} / \mathrm{Pt}$ thermocouples equipped with the quartz glass insulation tubes. Subsequently, the inner quartz glass insulation tubes of both thermocouples $\mathrm{Au} / \mathrm{Pt} 12-01$ and $\mathrm{Au} / \mathrm{Pt}$ 13-03 were replaced with pure aluminium oxide tubes $\left(\mathrm{Al}_{2} \mathrm{O}_{3}, 99.7 \%\right)$, annealed to remove any possible cold-work and then re-measured at all fixed points.

\section{RESUlts}

The homogeneity measurements of the two thermocouples $\mathrm{Au} / \mathrm{Pt}$ 12-01 and $\mathrm{Au} / \mathrm{Pt} 13-03$ which were performed in the salt bath at $300{ }^{\circ} \mathrm{C}$ exhibited only negligible differences between the initial scans and the scans performed after experiments. These emf differences of the scans along the measured length of the thermocouples were smaller than $0.1 \mu \mathrm{V}$ and $0.5 \mu \mathrm{V}$ for $\mathrm{Au} / \mathrm{Pt} 13-03$ and $\mathrm{Au} / \mathrm{Pt} 12-01$, respectively. This indicates that the thermocouples within the region on which the homogeneity scan was performed, were not exposed to any chemical contamination, mechanical strain or any other influence that could affect their Seebeck coefficient.

The maximum emf deviations found as results of the homogeneity scanning at the freezing point of silver over the length of $12 \mathrm{~cm}$ were $1.8 \mu \mathrm{V}$ for $\mathrm{Au} / \mathrm{Pt} 13-03$ and $2.6 \mu \mathrm{V}$ for 
$\mathrm{Au} / \mathrm{Pt}$ 12-01. The repeated measurements before and after the position testing have shown only small differences from the initial values in the order of $0.5 \mu \mathrm{V}$ for $\mathrm{Au} / \mathrm{Pt} 12-01$ and $0.6 \mu \mathrm{V}$ for $\mathrm{Au} / \mathrm{Pt} 13-03$.

The comparison of fixed-point measurements done by the thermocouples $\mathrm{Au} / \mathrm{Pt} 12-01, \mathrm{Au} / \mathrm{Pt} 13-03$ with quartz glass $\left(\mathrm{SiO}_{2}\right)$ and aluminium oxide $\left(\mathrm{Al}_{2} \mathrm{O}_{3}\right)$ insulation have shown clear differences in the measured emf. Based on the measured data the generated emf with the use of aluminium oxide insulation was higher through the whole measured temperature range from $419{ }^{\circ} \mathrm{C}$ to $962{ }^{\circ} \mathrm{C}$. The measured values have furthermore shown an increasing difference of emf with temperature with the peak at the fixed point of silver. The maximum measured at $\mathrm{Ag}$ point $\left(961.78^{\circ} \mathrm{C}\right)$ differences of emf were $6.8 \mu \mathrm{V}\left(0.273^{\circ} \mathrm{C}\right)$ for $\mathrm{Au} / \mathrm{Pt} 12-01$ and $11.5 \mu \mathrm{V}\left(0.462{ }^{\circ} \mathrm{C}\right)$ for $\mathrm{Au} / \mathrm{Pt} 13-03$. The detailed results are presented in Table 2.

Table 2. Emfs measured at fixed points when using the $\mathrm{Au} / \mathrm{Pt}$ thermocouples 12-01 and 13-03 with quartz glass and aluminium oxide insulation tubes.

\begin{tabular}{|c|c|c|c|c|}
\hline Thermometer & \multicolumn{4}{|c|}{$\mathrm{Au} / \mathrm{Pt} 12-01$} \\
\hline & \multicolumn{2}{|c|}{$\operatorname{emf}[\mu V]$} & \multirow{3}{*}{$\underset{[\mu \mathrm{V}]}{\Delta \operatorname{emf}^{-}}$} & \multirow{3}{*}{$\begin{array}{c}\Delta \mathbf{t} \\
{\left[{ }^{\circ} \mathbf{C}\right]}\end{array}$} \\
\hline & \multirow[t]{2}{*}{ (Quartz) } & \multirow[t]{2}{*}{$\left(\mathrm{Al}_{2} \mathrm{O}_{3}\right)$} & & \\
\hline Fixed point & & & & \\
\hline $\mathrm{Ag}$ & 16084.9 & 16091.7 & 6.8 & 0.273 \\
\hline $\mathrm{Al}$ & 9299.3 & 9300.6 & 1.3 & 0.065 \\
\hline $\mathrm{Zn}$ & 4933.2 & 4934.0 & 0.8 & 0.050 \\
\hline Thermometer & \multicolumn{4}{|c|}{$\mathrm{Au} / \mathrm{Pt} 13-03$} \\
\hline & \multicolumn{2}{|c|}{$\operatorname{emf}[\mu \mathrm{V}]$} & \multirow{3}{*}{$\underset{[\mu \mathrm{V}]}{\Delta \mathrm{emf}^{-}}$} & \multirow{3}{*}{$\begin{array}{c}\Delta \mathbf{t} \\
{\left[{ }^{\circ} \mathrm{C}\right]}\end{array}$} \\
\hline & \multirow{2}{*}{ (Quartz) } & \multirow[t]{2}{*}{$\left(\mathrm{Al}_{2} \mathrm{O}_{3}\right)$} & & \\
\hline Fixed point & & & & \\
\hline $\mathrm{Ag}$ & 16101.6 & 16113.1 & 11.5 & 0.462 \\
\hline $\mathrm{Al}$ & 9312.6 & 9315.0 & 2.4 & 0.119 \\
\hline $\mathrm{Zn}$ & 4942.6 & 4943.0 & 0.4 & 0.025 \\
\hline
\end{tabular}

\section{DISCUSSION}

Comparison measurements in fixed-point cells with the thermocouples $\mathrm{Au} / \mathrm{Pt} 12-01$ and $\mathrm{Au} / \mathrm{Pt} 13-03$ with the quartz glass insulation tubes and replaced aluminium oxide insulation tubes have shown an evident effect on the measured emf. The observed lower emfs, when a quartz glass insulation tube was used, is believed to be caused by a leakage effect. Leakage effects were observed and investigated by Berry and Zang [10]-[15] in HTSPRTs using quartz glass and silica glass insulation. Their findings have shown that this effect occurs in a temperature range from $600^{\circ} \mathrm{C}$ to $1100{ }^{\circ} \mathrm{C}$. Decreasing insulation resistance with increasing temperature is also described in these publications as a possible cause of the disturbance.

To be able to confirm the mechanisms previously described, a relationship between the decreasing resistances with increasing temperature for each individual material needed to be determined. The specific resistivity of quartz glass and aluminium oxide in comparison is shown in Fig. 2.

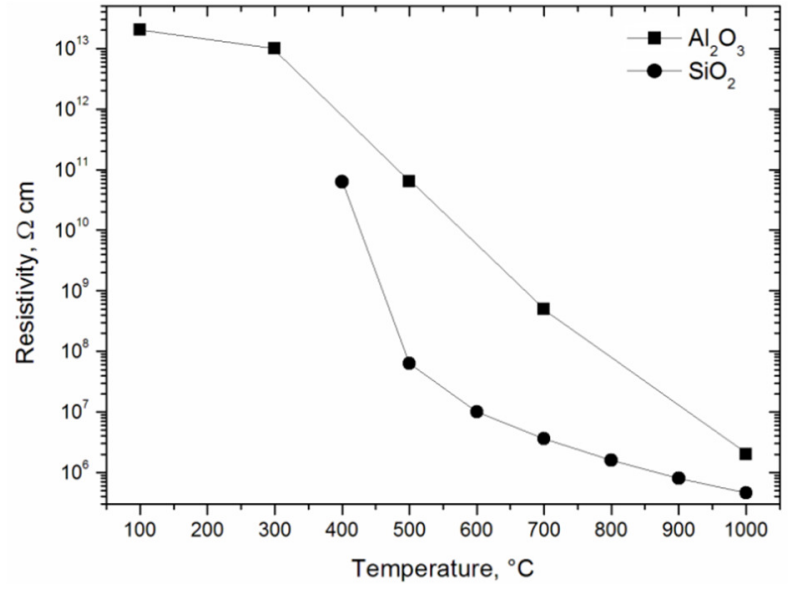

Fig.2. Resistivity of quartz glass $\left(\mathrm{SiO}_{2}\right)$ and aluminium oxide $\left(\mathrm{Al}_{2} \mathrm{O}_{3}\right)$ at elevated temperatures [16].

As can be seen both of the materials have a different decreasing trend of resistivity with temperature elevation. When compared at the same temperatures it is clear that aluminium oxide $\left(\mathrm{Al}_{2} \mathrm{O}_{3}\right)$ has a volume resistance which is several levels of magnitude higher than that of the quartz glass $\left(\mathrm{SiO}_{2}\right)$ material. This corresponds with our previous findings and the assumption that the insulation material resistance change influences the measurements with $\mathrm{Au} / \mathrm{Pt}$ thermocouples.

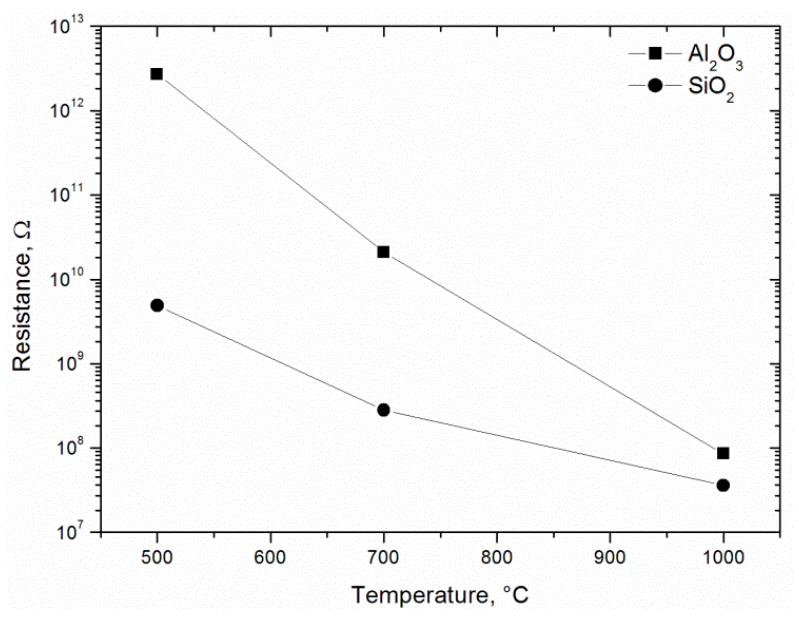

Fig.3. Resistance of a $1 \mathrm{~cm}$ long insulation tube segment the quartz glass $\left(\mathrm{SiO}_{2}\right)$ and aluminium oxide $\left(\mathrm{Al}_{2} \mathrm{O}_{3}\right)$ in the temperature range from $500{ }^{\circ} \mathrm{C}$ up to $1000^{\circ} \mathrm{C}$.

As the wall thickness of the insulation material influences the resulting final resistance and the thickness differed with the use of quartz glass and aluminium oxide tubes, it was necessary to take into account this parameter as well.

The resulting resistance for a $1 \mathrm{~cm}$ segment of quartz glass and aluminium oxide for the temperature range from $500{ }^{\circ} \mathrm{C}$ up to $1000^{\circ} \mathrm{C}$ can be found in Fig.3. This graph shows that even after taking into account the different wall thicknesses, the aluminium oxide insulation tube maintains its higher resistance at a value of $8.5 \times 10^{7} \Omega$ at $1000{ }^{\circ} \mathrm{C}$ in comparison 
to quartz glass which only has a resistance of $3.6 \times 10^{7} \Omega$ at the same temperature.

Based on these findings there is a strong indication that quartz glass suffers from a reduction of insulation resistance at higher temperatures, and an interaction between the thermoelements becomes possible.

\section{CONCLUSION}

The investigation of the $\mathrm{Au} / \mathrm{Pt}$ thermocouples which were made by using solely quartz glass as an insulation material exhibited considerable deficiencies when used at temperatures higher than about $660{ }^{\circ} \mathrm{C}$. This unsatisfying performance is suspected to be caused by the reduced insulation resistance of the single thin walled quartz glass tubes used. If it were possible to use quartz glass tubes with thicker walls resulting in higher insulation resistance, the benefit of the unhindered movement of the thermoelements in the smooth quartz glass holes might compensate the effects of the reduced insulation resistance found in this work.

\section{ACKNOWLEDGMENT}

The work presented was made thanks to the joint research project SIB10 Novel Techniques for Traceable Temperature Dissemination (NOTED) funded by the European Metrology Research Program (EMRP) and the European NMIs. The EMRP is jointly funded by the EMRP participating countries within EURAMET and the European Union. The authors would like to furthermore thank the Faculty of Engineering of the Slovak University of Technology in Bratislava, the grant agency APVV projects number (15-0295 and 15-0164); VEGA projects number (1/0098/18, 1/0556/18, and 1/0610/17) and KEGA projects number (006 / STU-4/2018 and 039STU-4/2017).

\section{REFERENCES}

[1] Preston-Thomas, H. (1990). The International Temperature Scale of 1990 (ITS-90). Metrologia, 27 (1), p. 3-10.

[2] Moiseeva, N.P., Pokhodun, A.I., Mangum, B.W., Strouse, G.F. (1999). Investigation of stability of HTPRTs at high temperature. In $7^{\text {th }}$ International Symposium on Temperature and Thermal Measurement in Industry and Science (TEMPMEKO 99). Delft, Netherlands: NMi Van Swinden Laboratorium, 371376.

[3] Berry, R.J. (1988). AC and DC insulation leakage errors in platinum resistance thermometers up to $1100{ }^{\circ} \mathrm{C}$. National Research Council Canada (NRCC) Report No. 29860.

[4] Moiseeva, N.P. (2004). Improved design for 0.6-ohm HTSPRTS: Reducing the leakage error and increasing the stability. In $9^{\text {th }}$ International Symposium on Temperature and Thermal Measurements in Industry and Science (TEMPMEKO 2004). Zagreb, Croatia: Laboratory for Process Measurement, Faculty of Mechanical Engineering and Naval Architecture, 433438.
[5] Furukawa, G.T., Strouse, G.F. (2001). Investigation of the non-uniqueness of the ITS-90 in the range $660{ }^{\circ} \mathrm{C}$ to $962{ }^{\circ} \mathrm{C}$. In 8 th International Symposium on Temperature and Thermal Measurements in Industry and Science (TEMPMEKO 2001). Berlin, Germany: VDE-Verlag.

[6] Coppa, G., Merlone, A. (2016). A study on ITS-90 type 3 non-uniqueness between freezing points of $\mathrm{Al}$ and Ag. Measurement, 89, 109-113.

[7] Ferdouse, J., Ballico, M. (2007). Stability studies of a new design $\mathrm{Au} / \mathrm{Pt}$ thermocouple without a strain relieving coil. International Journal of Thermophysics, 28 (6), 1822-1831.

[8] Ripple, D., Fellmuth, B., Fischer, J., Machin, G., Steur, P., Tamura, O., White, D.R. (2008). Report from the Mise en Pratique Task Group: The next international tem-perature scale and the mise en pratique for the definition of the kelvin. CCT/08-17/rev. http://www.bipm.org/cc/CCT/Allowed/24/D17_rev_M ePK_Report_2008c.pdf

[9] Gotoh, M., Hill, K.D., Murdock, E.G. (1991). A gold/platinum thermocouple reference table. Review of Scientific Instruments, 62 (11), 2778-2791.

[10] Berry, R.J. (1995). Analysis and control of electrical insulation leakage in platinum resistance thermometers up to $1064{ }^{\circ} \mathrm{C}$. Metrologia, 32 (1), 11-25.

[11] Berry, R.J. (1966). Platinum resistance thermometry in the range $630-900{ }^{\circ} \mathrm{C}$. Metrologia, 2 (2), 80-90.

[12] Berry, R.J. (1988). AC and DC insulation leakage errors in platinum resistance thermometers up to $1100{ }^{\circ} \mathrm{C}$, Part 2. National Research Council Canada (NRCC) Report No. 29861.

[13] Berry, R.J., Zhang, J. (1989). AC and DC insulation leakage errors in platinum resistance thermometers up to $1100{ }^{\circ} \mathrm{C}$, Part 3. National Research Council Canada (NRCC) Report No. 29862.

[14] Berry, R.J., Zhang, J. (1986). In Proceedings of the International Symposium on Temperature Measurement in Industry and Science. Beijing, China: China Academic Publishers, 157-163.

[15] Zhang, J., Berry, R.J. (1985). AC and DC insulation leakage in platinum resistance thermometers up to $750{ }^{\circ} \mathrm{C}$. Metrologia, 21 (4), 207-223.

[16] Shackelford, J.F., Alexander, W. (2001). CRC Material Science and Engineering Handbook, Third edition. CRC Press, ISBN 0-8493-2696-6

Received May 2, 2019 Accepted August 30, 2019 